Proc. Estonian Acad. Sci. Geol., 1998, 47, 2, 51-76

\title{
DISTRIBUTION OF SILURIAN AND LOWER DEVONIAN VERTEBRATE MICROREMAINS AND CONODONTS IN THE BAILLIE-HAMILTON AND CORNWALLIS ISLAND SECTIONS, CANADIAN ARCTIC
}

\author{
Tiiu MÄRSS ${ }^{\mathrm{a}}$, Michael CALDWELL ${ }^{\mathrm{b}}$, Pierre-Yves GAGNIER ${ }^{\mathrm{c}}$,
} Daniel GOUJET ${ }^{\mathrm{d}}$, Peep MÄNNIK ${ }^{\mathrm{a}}$, Tõnu MARTMA ${ }^{\mathrm{a}}$, and Mark WILSON ${ }^{\mathrm{b}}$

a Institute of Geology at Tallinn Technical University, Estonia pst. 7, EE-0001 Tallinn, Estonia; e-mail:marss@gi.ee

b Department of Biological Sciences, Laboratory of Vertebrate Palaeontology, University of Alberta, Edmonton, Alberta T6G 2E9, Canada

c Grande Galerie de l'Évolution, 36 rue Geoffroy Saint-Hilaire, 75005 Paris, France

d Laboratoire de Paléontologie, Muséum national d'Histoire naturelle et URA 12 du CNRS, 8 rue Buffon, 75005 Paris, France

Received 27 October 1997, in revised form 3 December 1997

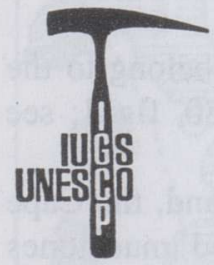

IGCP Project 328

Palaeozoic

Microvertebrates

IGCP Project 406

Circum-Arctic

Palaeozoic Vertebrates

Abstract. We studied the distribution of vertebrate microremains and conodonts, and measured carbon isotope values in several sections on Baillie-Hamilton and Cornwallis islands from the Upper Llandovery, Silurian, up to Lower Devonian. Thelodont genera Loganellia, Shielia, Goniporus, Katoporodus, Nikolivia, Canonia, and Turinia, and seven new thelodont taxa were recognized. Four (three?) genera of anaspids and three chondrichthyans were found for the first time. Acanthodians include Gomphonchus sandelensis, Nostolepis striata, N. gracilis, Poracanthodes punctatus, and $P$. porosus types of scales. Ten vertebrate assemblages were established. Conodonts, ostracodes, and carbon isotope values were used for age determination. Conodonts (Pterospathodus cf. amorphognathoides, Pt. pennatus procerus, Apsidognathus lobatus, A. aff. ruginosus, Aspelundia fluegeli, etc.) indicate the Telychian age for the lower part of the studied Cape Phillips Formation. The WenlockLudlow boundary was recognized in the Baillie-Hamilton 2 section. Ozarkodina cf. eurekaensis, appearing in the uppermost part of the Barlow Inlet Formation in the eastern Cornwallis, allows correlation of these strata with the Lochkovian. Four carbon isotope positive peaks known from Wenlock, Ludlow, Přidoli, and Silurian-Devonian transition in the Baltic, the Central Urals, and Australia, are well represented in the Canadian Arctic.

Key words: Canadian Arctic, Silurian-Lower Devonian, vertebrates, conodonts, carbon isotope stratigraphy. 


\section{INTRODUCTION}

Following discussions with $\mathrm{R}$. Thorsteinsson and S. Turner during meetings held at the Institute of Sedimentary and Petroleum Geology, Calgary, and at the 1st Meeting of International Geological Correlation Programme (IGCP) Project 328 "Palaeozoic Microvertebrates" held in Miguasha, Canada, in 1991, plans for further field investigations on early vertebrates were initiated. It was found necessary to improve and detail the study of Silurian and Devonian agnathans and fishes, particularly with respect to microremains from the Canadian Arctic. The proposed field expedition took place in summer 1994. It was organized within the framework of IGCP Project 328 and financed by the Polar Continental Shelf Project, UNESCO/IUGS (for IGCP Project 328), McGill University Northern Studies, Natural Science and Engineering Research Council of Canada, and National Museum of Natural History, Paris.

The aim of the expedition was to examine the Silurian and lowermost Devonian sections of two islands, Cornwallis and Baillie-Hamilton (Fig. 1A), to take rock samples for getting vertebrate microremains, and to collect articulated specimens from the quarries discovered by R. Thorsteinsson. The purpose of these investigations was to establish the composition of early vertebrates, their variability, and distribution, and to use these data to subdivide and correlate the sections.

\section{MATERIAL}

Sedimentary rocks of Baillie-Hamilton and Cornwallis islands belong to the Franklinian Miogeosynclinian basin (Thorsteinsson \& Uyeno, 1980, fig. 1; see Fig. $1 \mathrm{~A}$ in this paper).

In the central part of the southern coast of Baillie-Hamilton Island, the Cape Phillips Formation, Silurian, is characterized by microlaminated mudstones (graptolitic shales), siltstones (sometimes micaceous), argillaceous skeletal grainstones, and coquinoid rudstones and floatstones of 5-30 cm in thickness (after Rohr et al., 1981, the thickness of the Cape Phillips Formation is $2743 \mathrm{~m}$ in the vicinity of Baillie-Hamilton Island). Ripple marks and two horizons of biohermal limestones have been documented. Conglomerates and breccia-like layers and oolitic grainstone interbeds are also present; the latter often include microscopic gastropods. Skeletal limestones are the most promising type of lithology to obtain vertebrate microremains. Limestones also contain silicified invertebrates, brachiopods, molluscs, ostracodes, corals, bryozoans, spongia, etc. Thorsteinsson \& Uyeno (1980, p. 21) regarded fossil debris beds probably to represent mass-flow deposits which have been transported from the shelf to, or down the slope. In these flows vertebrate remains can also be redeposited, thus biasing age determination. 


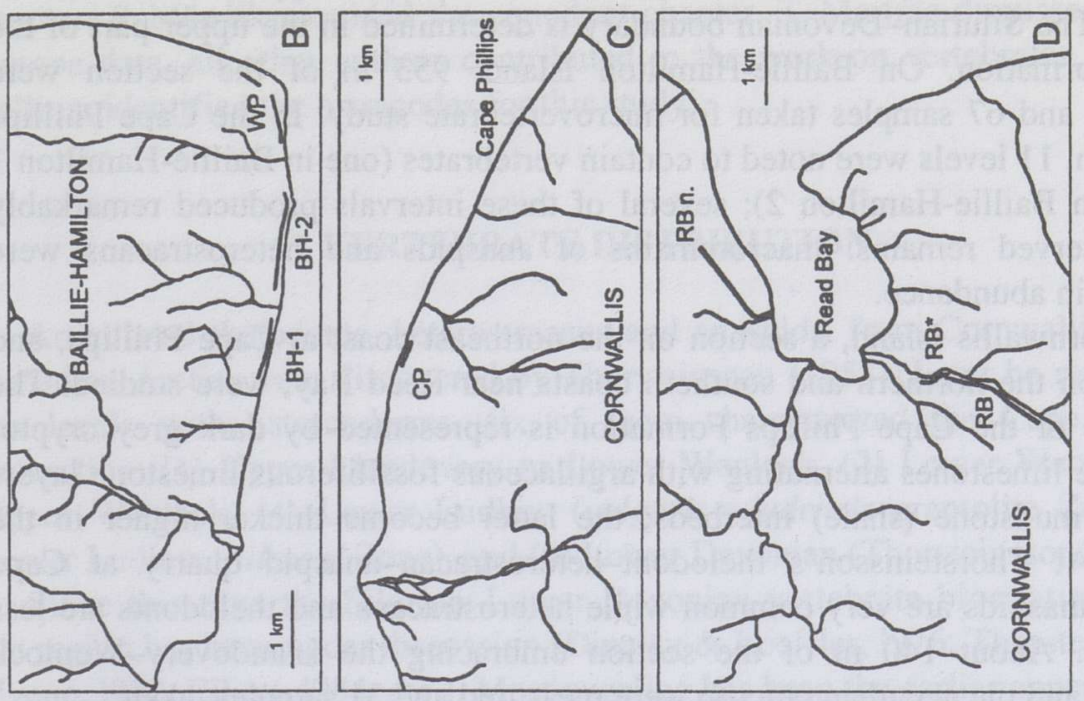

묻을

훙ํㅇ

छัญ

먼 으

$-50$

कo

业

$1 \equiv$

ำ ติ

i

ऽ동

๘ิ

- -

흥응음

등 क्ञ

돌

큰 든

๘

런

틀 ్ㅓㄴ 믐

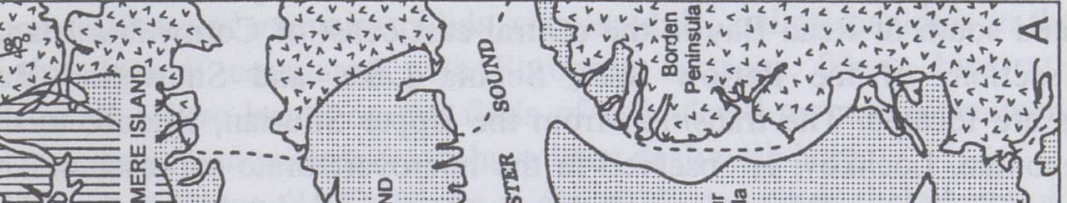

हี ज़

플

뉴요

๑ 등

클ำ

애으 을 등

สำ

.

.

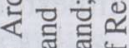

능

두

의 응

สิ ปี है

융 돈

등응

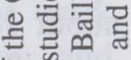

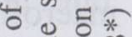

$403^{1}$

$40<\int^{2}$

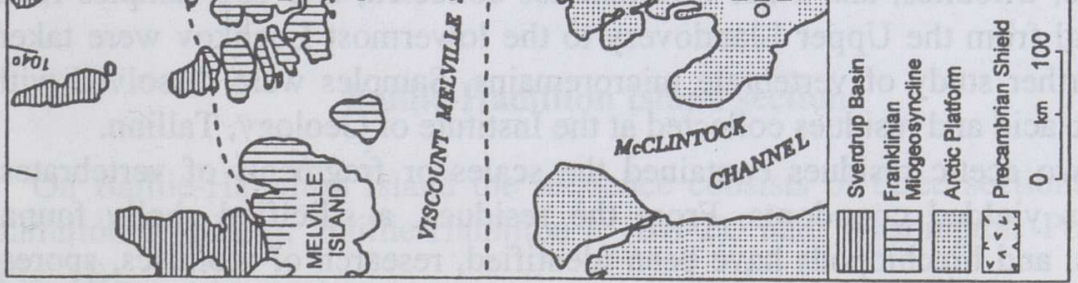

\&

的文

능 를

右

घิ

$<$ 음

$-1 .=7$

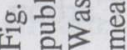


On the southeast corner of the island, siltstones of the Cape Phillips Formation are overlain by the argillaceous nodular limestones and secondary dolomites of the Sophia Lake Formation. Residues yield pyrite and dolomite crystals. The Silurian-Devonian boundary is determined in the upper part of the former formation. On Baillie-Hamilton Island, $953 \mathrm{~m}$ of the section were measured and 67 samples taken for microvertebrate study. In the Cape Phillips Formation, 11 levels were noted to contain vertebrates (one in Baillie-Hamilton 1 and ten in Baillie-Hamilton 2); several of these intervals produced remarkably well preserved remains: macroremains of anaspids and heterostracans were collected in abundance.

On Cornwallis Island, a section on the northeast coast at Cape Phillips, and sections on the northern and southern coasts near Read Bay, were studied. The stratotype of the Cape Phillips Formation is represented by dark grey cryptocrystalline limestones alternating with argillaceous fossiliferous limestone layers and thin mudstone (shale) interbeds; the latter become thicker higher in the section. At Thorsteinsson's thelodont-heterostracan-anaspid quarry at Cape Phillips, anaspids are very common while heterostracans and thelodonts are less numerous. About $140 \mathrm{~m}$ of the section embracing the Llandovery-Wenlock boundary and the agnathan outcrop were measured and 31 samples taken.

North and south of Read Bay in the central east coast of Cornwallis Island, the type sections of the Barlow Inlet, Sophia Lake, and Snowblind Bay formations are located. The transition from the Upper Silurian, Pridoli, to the Lower Devonian, Lochkov, is observed in the microvertebrate succession. The rocks vary: limestones, dolomites, and thin mudstone (shale) interbeds of the Barlow Inlet Formation are overlain by limestones and dolomites with siltstone and sandstone interbeds of the Sophia Lake Formation, and conglomerates, limestones, siltstones, and sandstones of the Snowblind Bay Formation. In this area $720 \mathrm{~m}$ of the section were measured and 30 samples taken. From the southern section heterostracan macrofragments and acanthodian spines were collected. From the talus of the northern section shields or fragments of different heterostracans, acanthodians, placoderms, porolepiforms, etc. were found.

In summary, during two weeks on Baillie-Hamilton and Cornwallis islands, about $1810 \mathrm{~m}$ of sequences were measured and lithologically studied, numerous macrofragments or articulated specimens of agnathans and fishes were found, eurypterids, trilobites, and other invertebrates collected, and 130 samples from the interval from the Upper Llandovery to the lowermost Lochkov were taken for the further study of vertebrate microremains. Samples were dissolved with $10 \%$ acetic acid and residues collected at the Institute of Geology, Tallinn.

Sixty-two acetic residues contained the scales or fragments of vertebrates, 73 samples yielded conodonts. From the residues, a silicified shelly fauna, ostracodes, and brachiopods have been identified, research of molluscs, spores, and chitinozoans is in progress, and work on scolecodonts has been started. Carbon isotopes have been studied from the same samples. The heterostracans, 
not dealt with here in any detail, are under study by R. Thorsteinsson, Calgary, E. Loeffler, Bristol, and D. Elliott, Flagstaff.

This paper is prepared as follows: T. Märss was responsible for the vertebrate chapter, P. Männik provided the conodont chapter, T. Martma discussed carbon isotope data, all other authors contributed to the work on vertebrates. L. Sarv, Tallinn, identified the ostracodes for this study.

\section{VERTEBRATE DISTRIBUTION}

Articulated thelodonts, heterostracans and anaspids, from Cornwallis Island, Canadian Arctic, were discovered by Thorsteinsson (1958). Later he recognized ten levels with ostracoderms, six of them characterized the Cape Phillips Formation: (1) Upper Llandovery or Lower Wenlock, (2) Lower Wenlock, (3) Upper Wenlock, (4) Lower Ludlow (vulgaris=ludensis graptolite Zone), (5) Lower Ludlow (nilssoni Zone), and (6) Lower Devonian (Thorsteinsson, 1967).

Since this time the Silurian-Lower Devonian vertebrate biostratigraphy of the region has been under discussion (Dineley \& Loeffler, 1976; Thorsteinsson \& Uyeno, 1980; Elliott, 1984; etc.). Most puzzling has been the earlier appearance of representatives of traquairaspidids, corvaspidids, and pteraspidids in the sections of this area if compared with European sections. These biostratigraphical discussions were based on the finds of articulated or macrospecimens, mainly heterostracans; microvertebrates have been dealt with less.

Turner \& Dixon (1970; Dixon et al., 1972) described thelodonts of the latest Wenlock or earliest Ludlow age of Prince of Wales Island. Vieth (1980) studied thelodonts, acanthodians, and elasmobranchs from the Lower Devonian of five arctic islands: Ellesmere, Axel Heiberg, Devon, Bathurst, and Prince of Wales. Sprague (1977) studied Siluro-Devonian thelodonts from the Cape Phillips Formation of Devon Island.

Preliminary results on the distribution of vertebrate microremains, conodonts, ostracodes, and on the carbon isotope study from the Lower Silurian up to Lower Devonian on two islands, Cornwallis and Baillie-Hamilton, were reported at the meeting of the IGCP Project 406 in Buckow (Märss et al., 1997). This work continues the studies on the agnathan and gnathostome composition and succession in that region.

\section{Baillie-Hamilton Island sections}

On Baillie-Hamilton Island the sequence consists of three sections, BaillieHamilton 1 (BH-1), Baillie-Hamilton 2 (BH-2), and Washington Point (WP) (Fig. 1B).

The BH-1 section is situated along the central part of the southern coast. The beginning of the measured section lies about 200 m east of an unnamed stream. 
In the BH-1 section (Fig. 2) acetic residues of samples at $0.0-65.5 \mathrm{~m}$ contained silicified fossils: tabulate and rugose corals, bryozoans, brachiopods, molluscs, trilobite fragments, ostracodes, crinoid stems, spicules of sponges, and rare scolecodonts. In the residues of mudstones (graptolitic shales) at this interval, sponges and rare brachiopods were found, crystals of quartz and pyrite were common, and on some levels $(40.5$ and $60.0 \mathrm{~m})$, aggregate chert occurred. Samples taken at $51.5 \mathrm{~m}$ were heavily silicified and did not dissolve at all. At $72.0 \mathrm{~m}$, the residue of microlaminated mudstones contained sponges, rare brachiopods and crinoids, and very small $(0.3-0.4 \mathrm{~mm})$ scales of Loganellia scotica and two heterostracans. One of them, Heterostraci? gen. et sp. 1, has elongate, striated ridges on the outer surface and a pulp opening for each ridge in the basal part. Of seven other specimens, there are several with a single ridge that resembles thelodont scales. Heterostraci gen. et sp. 2 has scales with a wide, flat median rib, and paired lateral rib. Small, unsculptured Theloduslike scales present in the fractions could also be bucco-pharyngeal scales of Loganellia. In the coquinoid rudstone at $81.0 \mathrm{~m}$, in addition to the above mentioned species, Heterostraci gen. et sp. 3 was found, characterized by strongly elongated convex ridges. Astraspidida? gen. et sp. sensu KaratajūteTalimaa \& Predtechenskyj (1995) also appears. Our material shows two very small tesserae with a central tubercle and a row of tubercles around the central one. The systematic position of this taxon is not clear. In the same sample a denticulated platelet of the branchial area of Loganellia was found. At $85.5 \mathrm{~m}$ Shielia sp. nov. and Birkeniida gen. et sp. 1 appear, and Loganellia scotica is present for the last time. Most probably Birkeniida gen. et sp. 1 with a very narrow and deep basal rib of finely tuberculated scales belongs to the genus Birkenia, or something close to that taxon, known from the Upper LlandoveryLower Wenlock of Scotland. A fragment of another heterostracan should be mentioned as well.

Macrofragments of anaspid squamation were found at $89.0 \mathrm{~m}$. The beds containing articulated thelodonts, heterostracans, and anaspids lie at $90.0-92.5 \mathrm{~m}$. A big eurypterid was also found at the $90.0-92.5 \mathrm{~m}$ interval. On this level the diversity of vertebrates is highest in the $\mathrm{BH}-1$ section.

Microlaminated calcareous mudstone with brachiopods, ostracodes, bryozoans, and graptolites occurring at $90.0 \mathrm{~m}$ contained three new thelodont genera each represented by one species, and three heterostracans different from those in the lower beds. There is a gap in the vertebrate distribution between 85.5 and $90.0 \mathrm{~m}$ in this section. Thelodonti gen. et sp. nov. 1 has scales with a high base and rounded, deeply crenulated margins around relatively flat crowns; Thelodonti gen. et sp. nov. 2 has big (up to $2.3 \mathrm{~mm}$ ) scales typical of the Loganellia group;

Fig. 2. Distribution of vertebrates (black squares) and conodonts (black triangles) in the BaillieHamilton sequence. Most of the sequence belongs to the Cape Phillips Formation; the upper part of the Washington Point section represents the Sophia Lake Formation (Thorsteinsson \& Uyeno, 1980). A1-A7, vertebrate assemblages; TQ, Thorsteinsson Quarry. 


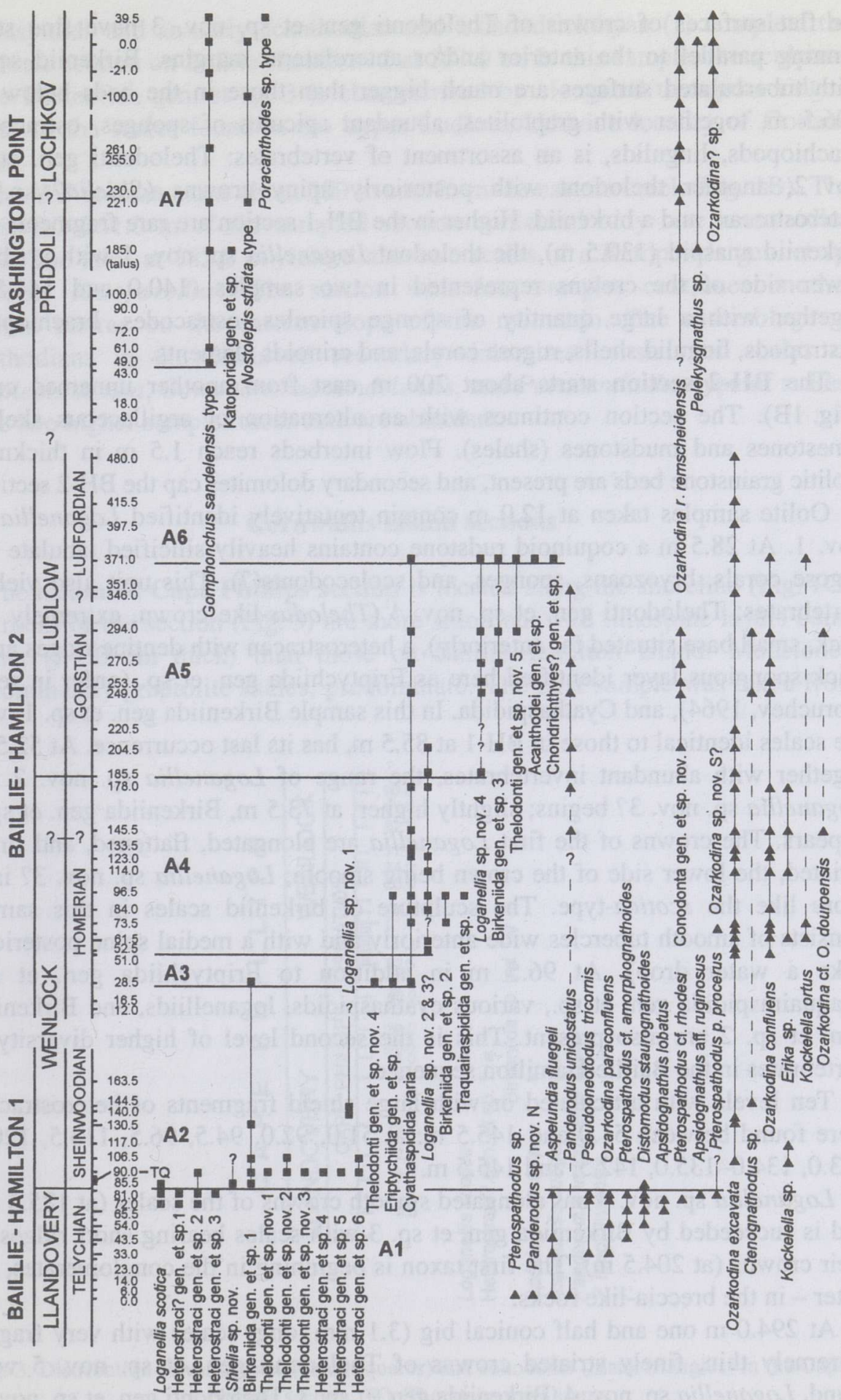


the flat surfaces of crowns of Thelodonti gen. et sp. nov. 3 have fine striae running parallel to the anterior and/or anterolateral margins. Birkeniid scales with tuberculated surfaces are much bigger than those in the beds below. At $106.5 \mathrm{~m}$, together with graptolites, abundant spicules of sponges, ostracodes, brachiopods, lingulids, is an assortment of vertebrates: Thelodonti gen. et sp. nov. 2, another thelodont with posteriorly spiny crowns (Shielia? sp.), a heterostracan, and a birkeniid. Higher in the $\mathrm{BH}-1$ section are rare fragments of a birkeniid anaspid $(130.5 \mathrm{~m})$, the thelodont Loganellia sp. nov. 1 with a ribbed lower side of the crowns represented in two samples (140.0 and $144.5 \mathrm{~m}$ ) together with a large quantity of sponge spicules, ostracodes, brachiopods, gastropods, lingulid shells, rugose corals, and crinoids elements.

The BH-2 section starts about $200 \mathrm{~m}$ east from another unnamed creek (Fig. 1B). The section continues with an alternation of argillaceous skeletal limestones and mudstones (shales). Flow interbeds reach $1.5 \mathrm{~m}$ in thickness. Oolitic grainstone beds are present, and secondary dolomites cap the BH-2 section.

Oolite samples taken at $12.0 \mathrm{~m}$ contain tentatively identified Loganellia sp. nov. 1. At $28.5 \mathrm{~m}$ a coquinoid rudstone contains heavily silicified tabulate and rugose corals, bryozoans, sponges, and scolecodonts(?). This unit also yielded vertebrates: Thelodonti gen. et sp. nov. 4 (Thelodus-like crown, extremely low neck, small base situated far anteriorly), a heterostracan with dentine ridges and a thick spongious layer identified here as Eriptychiida gen. et sp. (order in sensu Obruchev, 1964), and Cyathaspidida. In this sample Birkeniida gen. et sp. 1, with the scales identical to those in BH-1 at $85.5 \mathrm{~m}$, has its last occurrence. At $52.5 \mathrm{~m}$, together with abundant invertebrates, the range of Loganellia sp. nov. 2 and Loganellia sp. nov. 3 ? begins; slightly higher, at $73.5 \mathrm{~m}$, Birkeniida gen. et sp. 2 appears. The crowns of the first Loganellia are elongated, flattened, and finely striated, the lower side of the crown being smooth; Loganellia sp. nov. 3 ? is of more like the scotica-type. The sculpture of birkeniid scales in this sample consists of smooth tubercles wide anteriorly and with a medial spine posteriorly (like a water drop). At $96.5 \mathrm{~m}$ in addition to Eriptychiida gen. et sp., Traquairaspidida gen. et sp., various cyathaspidids, loganelliids, and Birkeniida gen. et sp. 2 are also present. This is the second level of higher diversity of vertebrates in the Baillie-Hamilton sequence.

Ten levels with articulated or with large shield fragments of heterostracans were found between 51.0 and $145.5 \mathrm{~m}$ : at 51.0, 92.0, 94.5, 96.5, 113.5, 120.0, $123.0,134.0-135.0,142.5$, and $145.5 \mathrm{~m}$.

Loganellia sp. nov. 4 has elongated smooth crowns of the scales (at $185.5 \mathrm{~m}$ ), and is succeeded by Birkeniida gen. et sp. 3 with scales bearing short ridges on their crowns (at $204.5 \mathrm{~m}$ ). The first taxon is beginning in the conglomerates, the latter - in the breccia-like rocks.

At $294.0 \mathrm{~m}$ one and half conical big ( $3.1 \mathrm{~mm}$ long) scales with very fragile, extremely thin, finely striated crowns of Thelodonti gen. et sp. nov. 5 were found. Loganellia sp. nov. 4, Birkeniida gen. et sp. 3, Thelodonti gen. et sp. nov. 5, 
cyathaspidids and an early acanthodian and a chondrichthyan (?) complete the vertebrate section on Baillie-Hamilton 2 at $371.0 \mathrm{~m}$. In this sample, the sculpture of the Birkeniida gen. et sp. 3 is characterized by elongated triangular ridges, similar to the scales found in the upper Ludlow, Uddvide locality of Gotland Island.

The WP section starts about $200 \mathrm{~m}$ east from the eastern creek (Fig. 1B). The lowest $8.0-261.0 \mathrm{~m}$ of the sampled section contained only rare acanthodian scales. The talus at $185.0 \mathrm{~m}$ yielded also two scales of a Katoporida gen. et sp. (probably Katoporodus). The section with four samples continues another hundred metres on the eastern slope of the mountain. The assemblage of acanthodians in the dissolved secondary dolomites consists of scales of Nostolepis striata, Gomphonchus sandelensis, and Poracanthodes-type of scales; in the two higher samples these taxa are abundant.

\section{Cornwallis Island sections}

The measured Cape Phillips section is located along the shoreline (Fig. 1C). The rocks of the section (Fig. 3) are more silicified, with limestone layers being thinner (5-30 cm thick) than those on Baillie-Hamilton Island. Mudstones, predominantly graptolite shales, predominate. The first sample was taken from

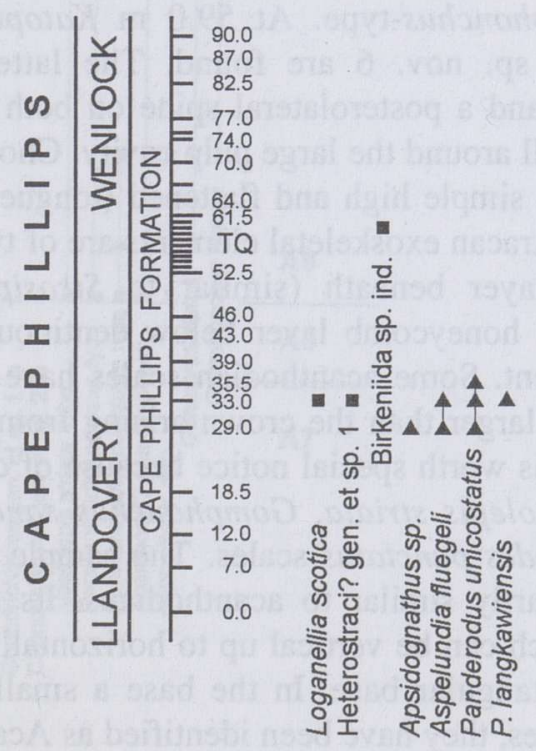

Fig. 3. Distribution of vertebrates (black squares) and conodonts (black triangles) in the Cape Phillips section. TQ, Thorsteinsson Quarry. 
beds on the right bank of a rivulet and the last below a unit of black chert. Microlaminated mudstones did not dissolve with the exception of those taken between 70.0 and $75.0 \mathrm{~m}$, which gave thin lamellae of detached rock. Residues, if available, contain ostracodes, brachiopods, fragments of crinoids, graptolites, spicules of sponges (at some levels all residue was made up of spicules only).

Only two samples contained vertebrate microremains, at $33.0 \mathrm{~m}$, Loganellia scotica and Heterostraci? gen. et sp. 1; and at $59.0 \mathrm{~m}$ Birkeniida sp. ind. A quarry with well preserved thelodonts, heterostracans, and anaspids lies between $54.0-60.0 \mathrm{~m}$. In this quarry at least 3 different heterostracans, 2(?) anaspids, 3-4 thelodonts, and 2-3(?) eurypterids were documented.

The Read Bay southern section consists of two parts: RB and RB* (the latter samples are marked with asterisks in the text and Fig. 4). The stratotype section of the Barlow Inlet Formation is on the left bank of a river entering into Read Bay on the southeast side. The measured section on the left bank of this river starts where a creek from the right side flows into it (Fig. 1D). The argillaceous carbonate rocks yielded a rich shelly fauna which mostly dissolved by acetic acid treatment. However, acid resistant scolecodonts (sometimes very abundant), lingulids, chitinous(?) membranes of eurypterids, and spicules of sponges are common; in some residues dolomitized ostracodes, gastropods, and crinoidal stem fragments were present. All samples dissolved well, and most of them contained vertebrate microremains. Samples with representative sets of scales complete the vertebrate succession in the Pridoli and lowermost Devonian part.

The samples at $0.0-51.0 \mathrm{~m}$ contain heterostracan fragments and acanthodian scales of the Gomphonchus-type. At $59.0 \mathrm{~m}$ Katoporodus cf. tricavus and Thelodonti gen. et sp. nov. 6 are found. The latter scale crowns have a posteromedial apex and a posterolateral spine on both sides, a low neck and a base that forms a wall around the large pulp cavity. Chondrichthyan scales are of two types: (a) single simple high and flattened (tongue-like) and (b) low multiodontodous. Heterostracan exoskeletal elements are of two main types: (a) ridges with a spongious layer beneath (similar to Strosipherus) and (b) typical cyathaspidids with a honeycomb layer below dentinous ridges. Gomphonchustype scales are present. Some acanthodian scales have a very deep rhomboidal base which is much larger than the crown arising from it. Argillaceous skeletal limestone at $87.0 \mathrm{~m}$ is worth special notice because of diverse acanthodian finds represented by Nostolepis striata, Gomphonchus sandelensis, Poracanthodes porosus, Poracanthodes punctatus scales. The sample also contains interesting scales of a taxon partly similar to acanthodians. Its scales have complicated ridged tubercles which can be vertical up to horizontally elongated and attached to a rounded or rectangular base. In the base a small opening occurs. Using morphological features, they have been identified as Acanthodei? gen. et sp. nov. Young scales that are semitransparent show internal chambers which are not common in acanthodians. Thin sections must be studied to identify this taxon more exactly. In the same sample, a plate about $0.8 \times 0.4 \mathrm{~cm}$ of Lophosteus 


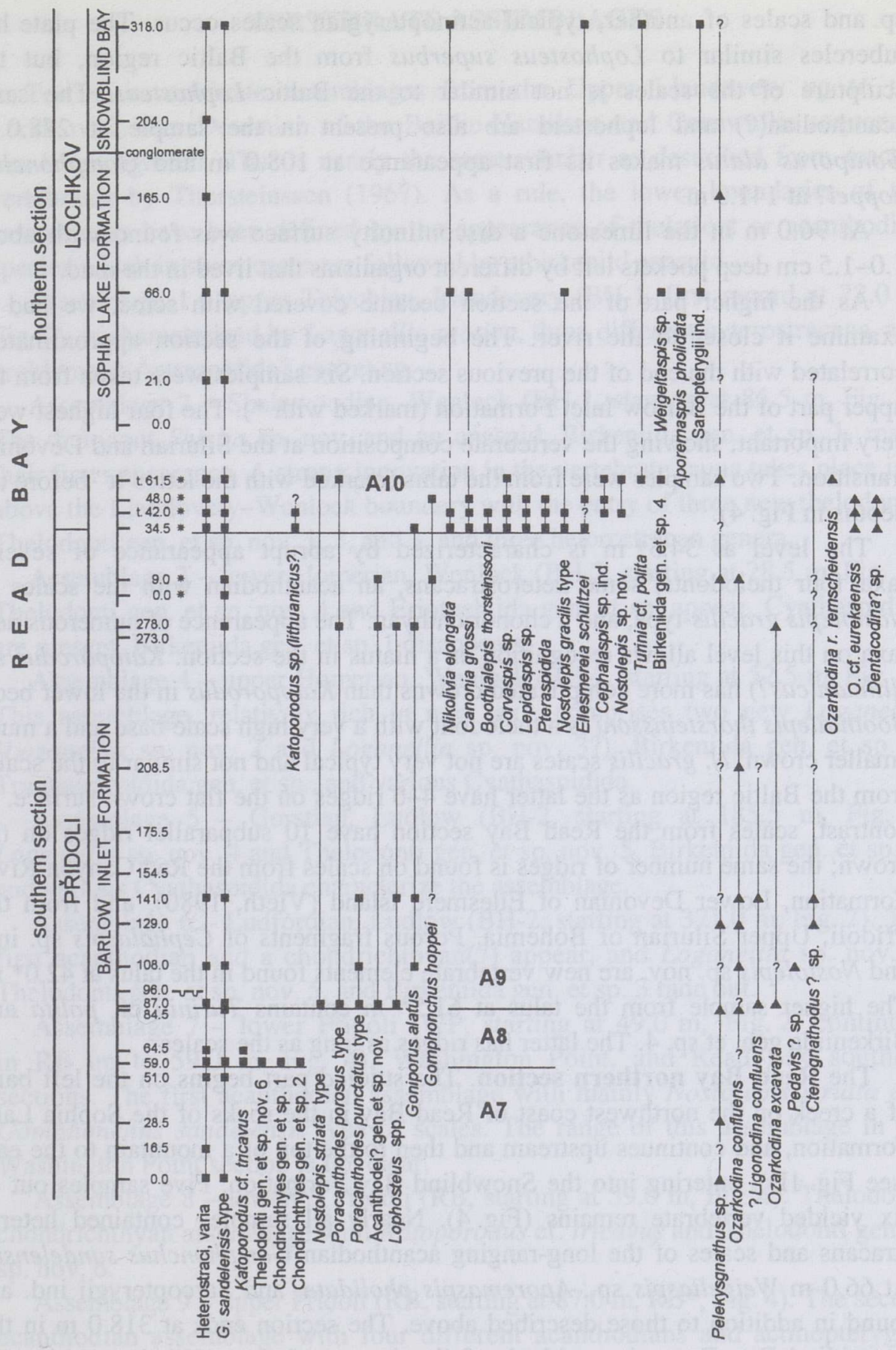

Fig. 4. Distribution of vertebrates (black squares) and conodonts (black triangles) in the Read Bay sequence. The Read Bay southern section consists of two parts: RB and RB*; talus is marked with letter " $t$ " before the depth. A7-A10, vertebrate assemblages. 
sp. and scales of another, typical actinopterygian scales occur. The plate has tubercles similar to Lophosteus superbus from the Baltic region, but the sculpture of the scales is not similar to the Baltic Lophosteus. The same acanthodian(?) and lophosteid are also present in the sample at $278.0 \mathrm{~m}$. Goniporus alatus makes its first appearance at $108.0 \mathrm{~m}$ and Gomphonchus hoppei? at $141.0 \mathrm{~m}$.

At $96.0 \mathrm{~m}$ in the limestone a discontinuity surface was found with about $1.0-1.5 \mathrm{~cm}$ deep pockets left by different organisms that lived in the mud.

As the higher part of the section became covered with scree, we had to examine it closer to the river. The beginning of the section approximately correlated with the end of the previous section. Six samples were taken from the upper part of the Barlow Inlet Formation (marked with*). The four highest were very important, showing the vertebrate composition at the Silurian and Devonian transition. Two samples were from the talus (marked with the letter " $t$ " before the depths in Fig. 4).

The level at $34.5^{*} \mathrm{~m}$ is characterized by abrupt appearance of several taxa: four thelodonts, some heterostracans, an acanthodian with the scales of Nostolepis gracilis-type, and a chondrichthyan. The appearance of numerous new taxa on this level allows recognition of a hiatus in the section. Katoporodus sp. (lithuanicus?) has more complicated crowns than Katoporodus in the lower beds. Boothialepis thorsteinssoni is a thelodont with a very high scale base and a much smaller crown; $N$. gracilis scales are not very typical and not similar to the scales from the Baltic region as the latter have 4-6 ridges on the flat crown surface. In contrast, scales from the Read Bay section have 10 subparallel ridges on the crown; the same number of ridges is found on scales from the Red Canyon River Formation, Lower Devonian of Ellesmere Island (Vieth, 1980), and from the Přidoli, Upper Silurian of Bohemia. Porous fragments of Cephalaspis sp. ind. and Nostolepis sp. nov. are new vertebrate elements found in the talus at $42.0 * \mathrm{~m}$. The higher sample from the talus at $61.5^{*} \mathrm{~m}$ contains Turinia cf. polita and Birkeniida gen. et sp. 4. The latter has ridges as long as the scales.

The Read Bay northern section. The studied part begins on the left bank of a creek on the northwest coast of Read Bay in the rocks of the Sophia Lake Formation, and continues upstream and then to the top of a mountain to the east (see Fig. 1D), entering into the Snowblind Bay Formation. Five samples out of six yielded vertebrate remains (Fig. 4). Nearly all samples contained heterostracans and scales of the long-ranging acanthodian Gomphonchus sandelensis. At $66.0 \mathrm{~m}$ Weigeltaspis sp., Aporemaspis pholidata, and Sarcopterygii ind. are found in addition to those described above. The section ends at $318.0 \mathrm{~m}$ in the Snowblind Bay Formation with the following vertebrates: Nikolivia elongata, Turinia cf. polita, different heterostracans, Gomphonchus sandelensis, Ellesmereia schultzei, and Sarcopterygii ind. 
Ten microvertebrate assemblages from the Upper Llandovery up to the Lochkov, Lower Devonian of the Baillie-Hamilton and Cornwallis sequence, can be recognized. That is nearly the same number as described from macrovertebrates by Thorsteinsson (1967). As a rule, the lower boundaries of the assemblages have been defined by the appearance of thelodont or acanthodian species which in some cases are followed by a birkeniid anaspid.

Assemblage 1 - upper Telychian, Llandovery (BH-1, first record at $72.0 \mathrm{~m}$, Fig. 2), is characterized by Loganellia scotica, three different heterostracans, and problematic Astraspidida? gen. et sp.

Assemblage 2 - Sheinwoodian, Wenlock (BH-1, starting at 85.5 m, Fig. 2). The thelodont Shielia sp. nov. and an anaspid, Birkeniida gen. et sp. 1, make their first appearance. A strong innovation in the vertebrate fauna takes place just above the Llandovery-Wenlock boundary with the entry of three new thelodonts, Thelodonti gen. et sp. nov. 1, 2, and 3, and three heterostracan genera.

Assemblage 3 - lower Homerian, Wenlock (BH-2, starting at 28.5 m, Fig. 2). Thelodonti gen. et sp. nov. 4 and Eriptychiida gen. et sp. appear, Cyathaspidids are present. Birkeniida gen. et sp. 1 disappears.

Assemblage 4 - upper Homerian, Wenlock (BH-2, starting at 52.5 m, Fig. 2). This assemblage, relatively rich in new taxa, comprises two new Loganellia (Loganellia sp. nov. 2 and Loganellia sp. nov. 3?), Birkeniida gen. et sp. 2, Traquairaspidida gen. et sp., and various Cyathaspidida.

Assemblage 5 - Gorstian, Ludlow (BH-2, starting at 185.5 m, Fig. 2). Loganellia sp. nov. 4 and Thelodonti gen. et sp. nov. 5, Birkeniida gen. et sp. 3, and various Cyathaspidida characterize the assemblage.

Assemblage 6 - Ludfordian, Ludlow (BH-2, starting at 371.0 m, Fig. 2). The first acanthodian and a chondrichthyan(?) appear, and Loganellia sp. nov. 4, Thelodonti gen. et sp. nov. 5, and Birkeniida gen. et sp. 3 fade out.

Assemblage 7 - lower Přidoli (WP, starting at 49.0 m, Fig. 2; continued in $\mathrm{RB}$ up to $59.0 \mathrm{~m}$, Fig. 4), Washington Point, and Read Bay southern sections. The first acanthodian assemblage with mainly Nostolepis striata and Gomphonchus sandelensis type of scales. The range of this assemblage in the Washington Point section is not clear.

Assemblage 8 - lower(?) Přidoli (RB, starting at $59.0 \mathrm{~m}$, Fig. 4). Thelodontchondrichthyan assemblage with Katoporodus cf. tricavus and Thelodonti gen. et sp. nov. 6.

Assemblage 9 - upper Přidoli (RB, starting at $87.0 \mathrm{~m}, \mathrm{RB}$, Fig. 4). The second acanthodian assemblage with four different acanthodians and actinopterygian Lophosteus spp., and thelodont Goniporus alatus.

Assemblage 10 - Lower Devonian, Lochkov (RB*, starting at $34.5^{*} \mathrm{~m}$, Fig. 4). Strongly renewed vertebrate fauna with thelodonts Nikolivia elongata, 
Canonia grossi, Boothialepis thorsteinssoni, Katoporodus sp. (lithuanicus?), heterostracans, and chondrichthyan Ellesmereia schultzei.

The vertebrates of the northern section need to be studied in more detail before drawing any conclusion.

\section{CONODONT DISTRIBUTION}

Early Palaeozoic conodonts are well known from many parts of the Canadian Arctic Archipelago (Uyeno, 1977, 1989, 1990; Mayr et al., 1980; Thorsteinsson \& Uyeno, 1980). From 62 samples processed from the Baillie-Hamilton sections 51 samples yielded conodonts. From Cornwallis Island, 27 samples from 47 studied were productive. The number of conodont elements per sample varied from 1 to more than 250 . Conodonts are relatively well preserved and amber in colour (Colour Alteration Index =1).

\section{Baillie-Hamilton Island sequence}

Three main associations indicating an age of late Llandovery (Telychian)earliest Wenlock, Wenlock-Ludlow, and Přidoli-Lochkov(?) for strata were established in the conodont sequence (Fig. 2). Most of the studied samples from Baillie-Hamilton Island come from beds corresponding to the Cape Phillips Formation. According to Uyeno (1990) the Cape Phillips Formation ranges from the Llandovery staurognathoides Zone (Ellesmere Island, Bjorne Peninsula, Eids M-66 well) to the Pragian kindlei Zone. However, the boundaries of the formation have been recognized to be diachronous.

\section{Late Llandovery-earliest Wenlock}

Among others the conodont fauna includes Panderodus sp. nov. N, Jeppsson and Männik, 1993, and Pterospathodus sp. (6.0 m), Aspelundia fluegeli $(6.0-81.0 \mathrm{~m})$, Pseudooneotodus tricornis $(33.0 \mathrm{~m})$, Ozarkodina paraconfluens $(33.0-81.0 \mathrm{~m})$, Pterospathodus cf. amorphognathoides (43.5-81.0 m), Apsidognathus lobatus $(65.5 \mathrm{~m})$, and Pterospathodus pennatus procerus and Apsidognathus aff. ruginosus $(81.0 \mathrm{~m})$. Together these conodonts indicate a Telychian age of the interval up to $81.0 \mathrm{~m}$. The appearance of Pt. cf. amorphognathoides at $43.5 \mathrm{~m}$ allows us to correlate at least the strata above this level with the $P t$. amorphognathoides amorphognathoides Zone. The range of Apsidognathus up to $81.0 \mathrm{~m}$ and its absence above that level permit us to conclude that the Llandovery and Wenlock boundary evidently lies in the interval of $81.0-85.5 \mathrm{~m}$ (see also Jeppsson \& Männik, 1993). 
The occurrence of Distomodus staurognathoides at $90.0 \mathrm{~m}$ indicates that this level is still below Datum 8 of the Ireviken Event and corresponds to the earliest Sheinwoodian strata (not younger than the murchisoni Zone - Jeppsson, in press).

\section{Wenlock-Ludlow}

The upper part of the section $\mathrm{BH}-1$ and the lower part of $\mathrm{BH}-2$ probably correspond to the Sheinwoodian and are characterized by very rare specimens of Ozarkodina excavata, Kockelella sp., and Panderodus sp.

Ning Zhang (1989; p. 52) listed from the middle part of the Baillie-Hamilton Island section ?Kockelella walliseri, Ozarkodina confluens, Pseudooneotodus bicornis, and Panderodus sp. (identified by T. T. Uyeno). Our 1994 collection from $\mathrm{BH}-1$, corresponding to the section noted above, did not contain $O$. confluens (this taxon appears only in the lower part of BH-2). Also, K. walliseri and Ps. bicornis are missing. However, if $K$. walliseri is truly present among conodonts identified by T. T. Uyeno, then the middle part of the section measured by Ning Zhang (e.g. sample C22184), and probably also that at BH-1, correspond to the $K$. walliseri Zone of Jeppsson (in press) and correlates with the late Sheinwoodian belophorus, rigidus and, probably, also with the lower part of the ellesae graptolite zones. The only fragments of Kockelella that might belong to $K$. ranuliformis or to $K$. walliseri come from BH-1 samples at 106.5 and 117.0 m (Fig. 2).

The occurrence of Dapsilodus sp. at $163.5 \mathrm{~m}$ in BH-1 and at $12.0 \mathrm{~m}$ in BH-2 indicates a deep-water origin of sediments (see also in Thorsteinsson \& Uyeno, 1980). However, the conodont Ctenognathodus sp. found at $144.5 \mathrm{~m}$ in $\mathrm{BH}-1$ is characteristic of nearshore or lagoonal rocks of the East Baltic (Viira, 1982; Jeppsson et al., 1994). Also, the ostracode Herrmannina sp. identified by L. Sarv from the same sample is known as an indicator of lagoonal environment.

At $51.0 \mathrm{~m}$ in BH-2 Ozarkodina confluens appears and $O$. excavata becomes one of the most common taxa. At the same level the number of conodont specimens in samples increases considerably and is usually well above ten in the higher strata. The conodont Erika sp., known on Gotland (L. Jeppsson, pers. comm.) from the Klinteberg, Upper Wenlock (Homerian), and Hemse Beds, Ludlow, occurs in the interval from $61.5 \mathrm{~m}$ below up to $145.5 \mathrm{~m}$ above.

At $61.5 \mathrm{~m}$ in BH-2 Kockelella ortus appears. This conodont is characteristic of the Slite Beds, Wenlock, in Gotland (Jeppsson et al., 1994).

At $145.5 \mathrm{~m}$, Ozarkodina cf. $O$. douroensis appears. On the western part of Cornwallis Island this taxon has been found together with Monograptus bohemicus bohemicus (Barrande) and $M$. chimaera subsp. cf. M. chimaera chimaera (Barrande) indicating the chimaera Zone of Early Ludlow age (Thorsteinsson \& Uyeno, 1980; Uyeno, 1990). Ozarkodina cf. O. douroensis has also been identified from the Cape Storm Formation in the eastern part of 
Cornwallis Island (Uyeno, 1977; pl. 41.1, figs. 7, 8) and from the Strathcona Fiord area, Ellesmere Island (Uyeno, 1990). In both regions it occurs in strata of Ludlow age as well.

At the same level $(145.5 \mathrm{~m})$ Panderodus unicostatus appears for the second time. That event is known from the Hemse Beds on Gotland (L. Jeppsson, pers. comm.) and the Sauvere Beds of the Paadla Stage, Lower Ludlow, on Saaremaa Island. However, a few specimens similar to Pand. unicostatus also occur in some samples below this level. Pand. unicostatus is almost continuously present up to the end of BH-2.

Most characteristic of the fauna from the interval of $204.5-294.0 \mathrm{~m}$ is a peculiar conodont of unknown origin, identified here as Conodonta gen. et sp. nov. From the interval with Conodonta gen. et sp. nov. also few fragments, probably belonging to Ctenognathodus, were recorded.

Appearing at $371.0 \mathrm{~m}$ Kockelella ortus, morphologically identical to the earliest early Ludfordian species from the Gerete-2 and Alsvik sections, Hemse Marls, Gotland (shown to P. Männik by L. Jeppsson), were found. However, similar elements, identified as $K$. variabilis, are illustrated from Member B of the Read Bay Formation (= lower part of the Barlow Inlet Formation according to Thorsteinsson \& Uyeno, 1980), Russell Island, Russell E-82 well, interval 1310.6-1328.9 m (Mayr et al., 1980; pl. 32.1, fig. 37). Identical conodonts were also found from the same formation $(6.1 \mathrm{~m}$ above the base; Thorsteinsson \& Uyeno, 1980; pl. 8, figs. 9, 10) in the eastern part of Cornwallis Island (Goodsir Creek section, GSC loc. 83 349). In the Canadian Arctic, the lowermost part of the Barlow Inlet Formation has been correlated with the uppermost Ludfordian, and the main part of it with the Přidoli (Thorsteinsson \& Uyeno, 1980; Uyeno, 1990). The disagreement in occurrences of this taxon in the sections on Gotland and in the Canadian Arctic is probably caused by our inadequate knowledge of the total range of it.

\section{Přidoli-Lochkov(?)}

The conodont fauna from the WP section is characterized by Ozarkodina remscheidensis remscheidensis. Good specimens of this taxon appear at $185.0 \mathrm{~m}$ (sample from the talus) and are present up to the end of the measured section. From the same sample (at $185.0 \mathrm{~m}$ ) Pelekysgnathus sp. has been found. A few fragments, probably belonging to the same taxon, have also been found at $0.0 \mathrm{~m}$. Elsewhere $O . r$. remscheidensis has been reported to have an extremely long range (Late Ludlow through the hesperius Zone to the lower part of the sulcatus Zone (Denkler \& Harris, 1985; Murphy \& Berry, 1983). But according to Uyeno (1990), in the Canadian Arctic islands, the total range of $O . r$ remscheidensis most probably corresponds to the hesperius to delta zones, e.g. to the earliest Devonian. Moreover, on Baillie-Hamilton Island, Monograptus uniformis, Icriodus 
woschmidti hesperius, and Warburgella rugulosa from the lower part of the Sophia Lake Formation, indicating an early Lochkovian age, were identified (Thorsteinsson \& Uyeno, 1980). Accordingly, it is possible that the section at Washington Point above $185.0 \mathrm{~m}$ correlates with the Lower Devonian. However, in Estonia $O$. $r$. remscheidensis is also well represented in the Ohesaare Stage corresponding to the upper Přidoli (Jeppsson et al., 1994).

In the upper part of the O. r. remscheidensis range, in samples 14-17, numerous elements of an unknown conodont resembling Ozarkodina appear (identified here as Ozarkodina? sp.). This taxon dominates in the samples at 0.0 and $39.5 \mathrm{~m}$.

\section{Cornwallis Island sections}

Five out of 31 samples from the Cape Phillips section contain conodonts (Fig. 3). The fauna at 29.0 and $33.0 \mathrm{~m}$ is typical Telychian - Apsidognathus sp., Aspelundia fluegeli, Panderodus unicostatus, and Pand. langkawiensis were identified. The sample taken at $18.5 \mathrm{~m}$ yielded some undiagnostic fragments of Oulodus, and at 35.5 and $46.0 \mathrm{~m}$ few fragments of Panderodus were found.

Conodonts are rather rare also in the Read Bay section (Fig. 4). Only the sample at $9.0 * \mathrm{~m}$, from the southern section, contains more than 250 specimens. Dominating Ozarkodina confluens, represented by different morphologies (also in the same sample), is most characteristic of the Barlow Inlet Formation. Here it appears at $64.5 \mathrm{~m}$ and ranges up to $9.0^{*} \mathrm{~m}$. Below the level of appearance of $O$. confluens, only Pelekysgnathus sp. has been identified. Although this conodont is rather rare in the studied collection, it is occasionally present through the Cornwallis Island section. From the middle and upper parts of the Barlow Inlet Formation, O. excavata and Ctenognathodus? sp. have been found.

All taxa listed above have long ranges and are stratigraphically undiagnostic. However, occurring in the samples at 87.0 and $141.0 \mathrm{~m}$, but probably also at $208.5 \mathrm{~m}$, is the conodont ?Ligonodina confluens (see Jeppsson, 1972). The conodont is known from Gotland, in strata of Late Ludlow age. Thorsteinsson \& Uyeno (1980) indicate that on Cornwallis Island the Barlow Inlet Formation ranges from Late Ludlow up to early Lochkov in age. At $108.0 \mathrm{~m}$ few fragments of Pedavis? sp. were found, probably also indicative of the latest Ludlow or early Prridoli age for the lower part of the studied section.

In the uppermost part of the Barlow Inlet Formation (sample $34.5^{*} \mathrm{~m}$ ) Ozarkodina cf. eurekaensis and Dentacodina? sp., showing the early Lochkovian age, appear. Both taxa occur also in the samples at $42.0 * \mathrm{~m}$ (talus) and $48.0 * \mathrm{~m}$. In the sample at $61.5^{*} \mathrm{~m}$ O. $r$. remscheidensis is well represented. In the strata above, in samples from the Sophia Lake and Snowblind Bay formations, only rare poorly preserved fragments of Pelekysgnathus sp. were found. 


\section{CARBON ISOTOPE STUDY}

For the carbon isotope study whole-rock samples were used (see Kaljo et al., 1997).

In the Baillie-Hamilton Island section (Fig. 5) four strong positive peaks have been established in the following intervals (within brackets are given the maximum values of $\delta^{13} \mathrm{C}$ in \%o): in the $\mathrm{BH}-1$ section at $85.5-117.0 \mathrm{~m}(+4.8)$, in the BH-2 section at 51.0-66.0 $\mathrm{m}(+4.1)$ and $346.0-397.5 \mathrm{~m}(+3.6)$, and in the WP section at $230.0 \mathrm{~m}(+4.7)$. The first and third peaks were dated by conodonts and can be correlated with the corresponding curves in the Baltic (Kaljo et al., 1996; in press), i.e. the lower Sheinwoodian (riccartonensis-belophorus graptolite Zone) and middle Ludfordian (bohemicus tenuis-kozlowskii Zone). The first peak follows directly the Ireviken Event (Aldridge et al., 1993). The second peak most probably corresponds to the positive shift in the middle Homerian (parvusnassa Zone) of the Baltic area and can represent the Mulde Event (Jeppsson et al., 1995). Similarity between them is supported by a following negative excursion of carbon isotope values. The third peak is comparable with the midLudfordian positive carbon isotope excursion close to the hedei or Lau Event in the Baltic (Märss, 1992; Jeppsson, 1996). The fourth peak in the WP section above the Silurian-Devonian boundary has its counterpart in Australia (Andrew et al., 1994) and the Central Urals (Chekhovich et al., 1990).

On Cornwallis Island, in the Read Bay southern sections, the studied samples have relatively low values of $\delta^{13} \mathrm{C}(-1.05$ to $+0.57 \%$ ) between 0.0 and $9.0 * \mathrm{~m}$. Starting from $34.5^{*} \mathrm{~m}$, it is $+2.5 \%$ and at $61.5 * \mathrm{~m}+3.4 \%$. In the East Baltic Pridoli the course of the curve is similar to that in the Canadian Arctic Pridoli. The beginning of the Devonian is once more marked with a positive curve.

\section{DISCUSSION}

The species and generic content of vertebrate microfossils and conodonts, and changes in them, allow subdivision of the Silurian and Lower Devonian sections of the Canadian Arctic islands for both graptolite and shelly facies. Two studied sequences, one along the southern Baillie-Hamilton coast, and the other on the central east coast of Cornwallis Island, overlap in the upper Pridoli and lower Lochkov part.

The thelodont Loganellia scotica, initially found and described from the Priesthill Group, Upper Llandovery of Scotland (Traquair, 1898), has a very wide geographic distribution (eastern Canada, British Isles, Norway, East Baltic, Timan-Pechora) and is always restricted to the Upper Llandovery. Astraspidida? gen. et sp. occurs in the Lower and Middle Llandovery of the Siberian Platform (Karatajūte-Talimaa \& Predtechenskyj, 1995). 


\section{Carbon isotope curves}

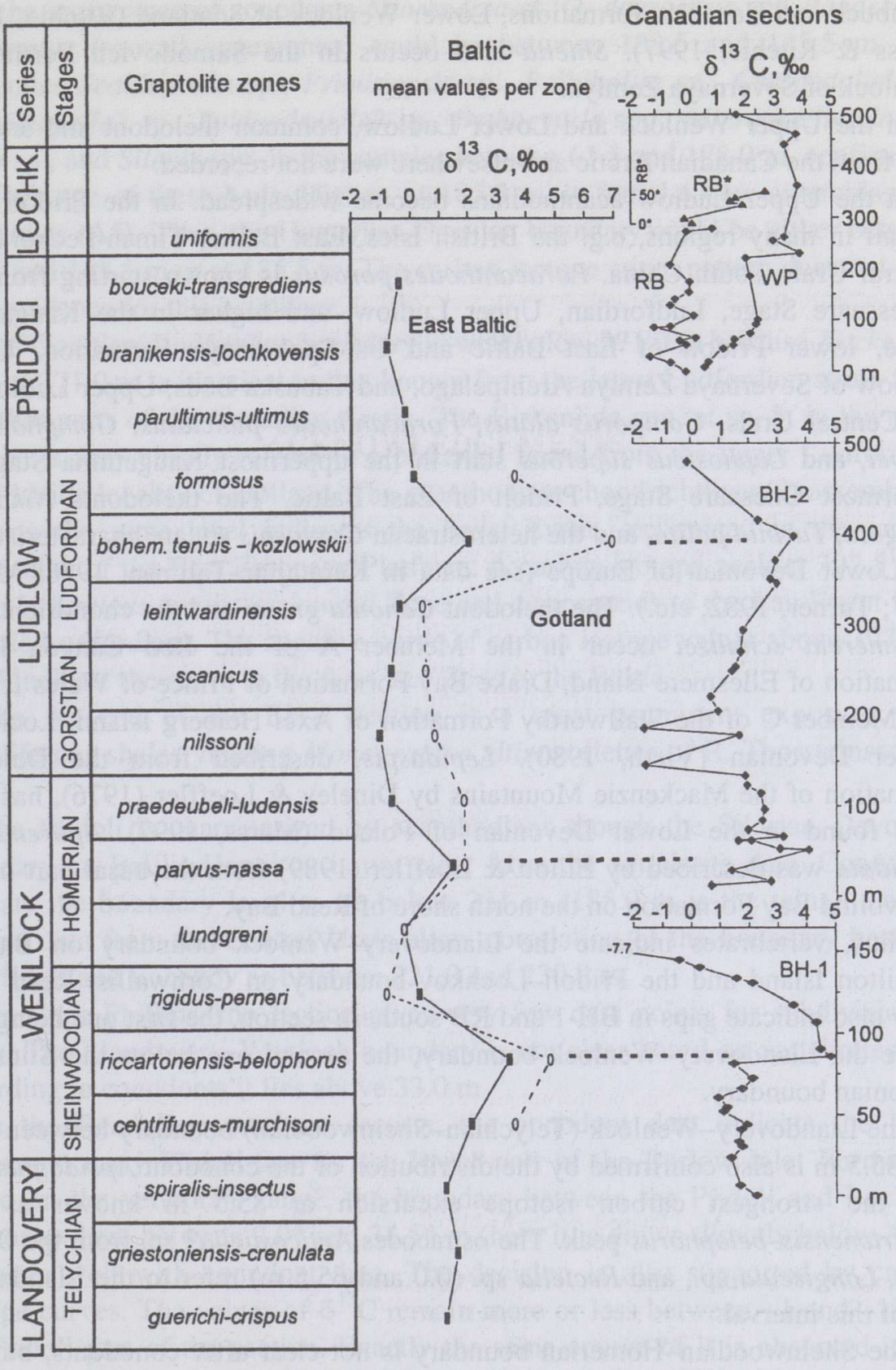

Fig. 5. Correlation of carbon isotope curves of the Silurian of the Baltic region (Kaljo et al., in press) and Canadian Arctic islands. BH-1, Baillie-Hamilton 1; BH-2, Baillie-Hamilton 2; WP, Washington Point sections of Baillie-Hamilton Island; RB and RB*, Read Bay southern sections of Cornwallis Island. Lochk., Lochkov. 
Shielia and Birkenia have been found from the Waterhead, and coeval Glenbuck and Henshaw formations, Lower Wenlock of Scotland (Ritchie, 1985; Märss \& Ritchie, 1997). Shielia also occurs in the Samoilovich Formation, Wenlock of Severnaya Zemlya.

In the Upper Wenlock and Lower Ludlow, common thelodont and anaspid taxa from the Canadian Arctic and elsewhere were not recorded.

In the Upper Ludlow acanthodians become widespread. In the Pridoli they prevail in many regions, e.g. the British Isles, East Baltic, Timan-Pechora, the Central Urals, south China. Poracanthodes porosus is known starting from the Kuressaare Stage, Ludfordian, Upper Ludlow, and higher in the Kaugatuma Stage, lower Prridoli of East Baltic and Ust-Spokoinaya Formation, Upper Ludlow of Severnaya Zemlya Archipelago, and Tabuska Beds, Upper Ludlow of the Central Urals. Goniporus alatus, Poracanthodes punctatus, Gomphonchus hoppei, and Lophosteus superbus start in the uppermost Kaugatuma Stage or lowermost Ohesaare Stage, Pridoli of East Baltic. The thelodonts Nikolivia elongata, Turinia polita, and the heterostracan Corvaspis sp. are characteristic of the Lower Devonian of Europe (see data in Karatajūte-Talimaa, 1978; Märss, 1997; Turner, 1982; etc.). The thelodont Canonia grossi and the chondrichthyan Ellesmereia schultzei occur in the Member A of the Red Canyon River Formation of Ellesmere Island, Drake Bay Formation of Prince of Wales Island, and Member $\mathrm{C}$ of the Stallworthy Formation of Axel Heiberg Island, Lochkov, Lower Devonian (Vieth, 1980). Lepidaspis, described from the Delorme Formation of the Mackenzie Mountains by Dineley \& Loeffler (1976), has also been found in the Lower Devonian of Poland (Märss, 1997). Aporemaspis pholidata was described by Elliott \& Loeffler (1989) from the basal part of the Snowblind Bay Formation on the north shore of Read Bay.

Thus, vertebrates indicate the Llandovery-Wenlock boundary on BaillieHamilton Island and the Prridoli-Lochkov boundary on Cornwallis, Read Bay. They also indicate gaps in $\mathrm{BH}-1$ and $\mathrm{RB}$ southern section, the first one being just above the Llandovery-Wenlock boundary, the second one below the SilurianDevonian boundary.

The Llandovery-Wenlock (Telychian-Sheinwoodian) boundary between 81.0 and $85.5 \mathrm{~m}$ is also confirmed by the distribution of the conodont Apsidognathus, and the strongest carbon isotope excursion at $85.5 \mathrm{~m}$ known as the riccartonensis-belophorus peak. The ostracodes Anticostiella? sp. from the $0.0 \mathrm{~m}$ level, Longiscula sp., and Rectella sp. (0.0 and $65.5 \mathrm{~m})$ refer to the Llandovery age of this interval.

The Sheinwoodian-Homerian boundary is not clear after conodonts, but the carbon isotope curve pattern allows of the presumption that this boundary remains after the rigidus-perneri minimum and before the lundgreni minimum, i.e. between the end of $\mathrm{BH}-1$ and beginning of $\mathrm{BH}-2$. The appearance of Erika sp. at $61.5 \mathrm{~m}$ in BH-2 evidently indicates the Homerian age. 
The Wenlock-Ludlow (Homerian-Gorstian) boundary in BH-2, if determined after the appearance of conodonts Ozarkodina cf. $O$. douroensis and Panderodus unicostatus (second appearance) could be between 133.5 and $145.5 \mathrm{~m}$. The ostracodes Scaldianella sp., Primitiopsis sp., Bolbibollia sp., Craspedobolbina sp., Libumella? sp., Eukloedenella? sp., Bythocypris spp., Microcheilinella sp., Olbia sp., and Silenis spp. in the samples between 61.5 and $178.0 \mathrm{~m}$, confirm the Wenlock age of these beds. Higher, at $185.5 \mathrm{~m}$, is found a new assemblage of vertebrates (A5). Thus, the Homerian-Gorstian boundary could be either between 133.5 and $145.5 \mathrm{~m}$ or at $185.5 \mathrm{~m}$. The carbon isotope curve pattern does not give good evidence for this boundary.

The Gorstian-Ludfordian boundary is well below 371.0 m because Kockelella ortus at $371.0 \mathrm{~m}$ is identical to that known from the latest Ludfordian strata from the other parts of the Canadian Arctic. The Birkeniida gen. et sp. 3, in the same sample, is very closely related to a birkeniid found from the upper Ludfordian, the Uddvide locality of Gotland. The acanthodian-chondrichthyan(?) assemblage (A6) on the same level indicates the hedei Event, recognized in the middle Ludfordian of the East European Platform. A carbon isotope peak at $397.5 \mathrm{~m}$ is in the bohemicus tenuis-kozlowskii Zone and corresponds to the Lau Event level (middle Ludfordian). The negative curve of carbon isotope values above $397.5 \mathrm{~m}$ could indicate the curve in the formosus Zone in the Baltic.

The far end of the BH-2 section is a most prominent exposure with petroliferous shales yielding Monograptus ultimus (letter of R. Thorsteinsson in 1997).

The Pridoli is characterized by acanthodians though the Silurian-Devonian boundary on Baillie-Hamilton is not clear from the vertebrate data. Conodonts indicate the boundary level to be below $221 \mathrm{~m}$ ( $185.0 \mathrm{~m}$ is the talus). Carbon isotope data from the Central Urals allow correlation of the boundary between the Přidoli and Lochkov as between 221.0 and $230.0 \mathrm{~m}$.

On Cape Phillips, the section gives very few data points for subdivision of strata. The Llandovery-Wenlock boundary is not clear based on vertebrates, but according to conodonts it lies above $33.0 \mathrm{~m}$.

In the Read Bay southern section, the conodont data indicate the latest Ludlow to early Prridoli age for the lower part of the Barlow Inlet Formation. Based on the vertebrate range, the boundary between the Pridoli and Lochkov lies somewhere between $9.0^{*}$ and $34.5^{*} \mathrm{~m}$ (here it is drawn directly below A10). It agrees well with conodont data. The decision is also supported by carbon isotope curves. The values of $\delta^{13} \mathrm{C}$ remain more or less between +1 and $-1 \%$ in the Pridoli part of the section. Exactly the same course of it is observed in the Ohesaare core, Estonia. Some samples from the upper part of the section (278.0, $0.0^{*}$, and $9.0 * \mathrm{~m}$ ) overlap. Also, in this section, the Silurian-Devonian boundary is well marked by new vertebrates at $34.5^{*} \mathrm{~m}$. In the interval between $9.0^{*}$ and $34.5^{*} \mathrm{~m}$ the carbon isotope curve turns strongly to the right. 


\section{CONCLUSIONS}

The distribution of exoskeletal microelements of vertebrate genera and species assists in the subdivision of the Silurian sequence into ten complexes. The best results are obtained by thelodonts, acanthodians, and chondrichthyans(?) with micromeric exoskeleton.

Some taxa identified in the Llandovery-Wenlock boundary beds, partly in the Upper Ludlow, and in the Pridoli and Lochkov, are similar to those found from the Russian Arctic Islands, the British Isles, the Baltic region, Podolia, and the Central Urals. The Upper Wenlock and Lower Ludlow taxa have a very restricted geographical distribution. Our material confirms that heterostracans, cyathaspidids, appeared in the Canadian Arctic already in the Telychian, Late Llandovery, traquairaspidids - in the Homerian, Late Wenlock, and were rather diverse. Thelodont genera and species of Llandovery and Wenlock age were more numerous than coeval thelodont genera and species in Europe or Asia. Only one genus of osteostracans was identified, and it enters in the lower Lochkov, Lower Devonian. Birkeniid anaspids as well as acanthodians were more or less of the same diversity as in Europe. Rare earliest chondrichthyans were already present in the Ludfordian(?), Late Ludlow, or early Přidoli. The most important finds were the exoskeletal elements having features of two higher taxa, transitional between thelodonts-heterostracans and acanthodians-chondrichthyans. They enable new phylogenetical reconstructions.

As to palaeogeographic analyses, it is difficult to say whether the differences in the Upper Wenlock and Lower Ludlow vertebrate fauna of northern Canada and Europe were caused by different latitudinal location of basins in the Silurian Period, facies differences (deep water or shallow water communities; e.g. nektic thelodonts, heterostracans, anaspids, chondrichthyans, and acanthodians have been found together with graptolites, but bottom dwelling osteostracans are rare as they inhabited areas further south on the carbonate platform) or some other reasons. The redeposition of sediments ("flows") and vertebrate remains could take place only during short time intervals and did not influence the succession of species.

The conodont fauna recognized in the studied sections indicates that the lower part of the Cape Phillips Formation on Baillie-Hamilton Island (in BH-1 up to $81.0 \mathrm{~m}$ ) and the Cape Phillips section on Cornwallis Island (at least up to $35.5 \mathrm{~m}$ ) correspond to the Telychian. The Wenlock-Ludlow boundary probably lies in the middle part (between 133.5 and $145.5 \mathrm{~m}$ ) of the BH-2 section, BaillieHamilton Island. The occurrence of Kockelella ortus of the Hemse type in the section $\mathrm{BH}-2$ (sample at $371.0 \mathrm{~m}$ ) indicates that strata above this level correspond to the Ludfordian. The appearance of Ozarkodina cf. eurekaensis in the Barlow Inlet Formation (Cornwallis Island, Read Bay section) correlates the beds above $34.5^{*} \mathrm{~m}$ with the Lochkovian. 
From the carbon isotope study it might be concluded that all four positive carbon isotope peaks known from the Wenlock-Přidoli and Silurian-Devonian transitions of the Baltic, Australia, and the Central Urals are well represented also in the Canadian Arctic.

\section{ACKNOWLEDGEMENTS}

The authors are indebted to Dr. D. Kaljo for the help in the interpretation of carbon isotope data. Discussions with Drs. A. Kleesment, M. Rubel, L. Sarv, and R. Einasto greatly aided the understanding of lithology and shelly fossil characteristics in the samples. Thanks are extended to Drs. E. Loeffler and R. Thorsteinsson for constructive discussions and useful suggestions on the Canadian Arctic vertebrates and age dating. The manuscript was much improved following the comments of reviewers.

\section{REFERENCES}

Aldridge, R. J., Jeppsson, L. \& Dorning, K. J. 1993. Early Silurian oceanic episodes and events. J. Geol. Soc. London, 150, 501-513.

Andrew, A. S., Hamilton, P. J., Mawson, R., Talent, J. A. \& Whitford, D. J. 1994. Isotopic correlation tools in the Mid-Palaeozoic and their relation to extinction events. APEA Journal, 34, 268-277.

Chekhovich, P. A., Zhivkovich, A. E., Medvedovskaya, N. I. \& Stepanova, N. A. 1990. Izotopnye repery v paleozoiskikh razrezakh Urala. Dokl. Akad. nauk SSSR, 313, 2, 423-426 (in Russian).

Denkler, K. E. \& Harris, A. G. 1985. Conodont biofacies and biostratigraphy of upper LudlowPridoli shallow-water carbonates in the Central Appalachians. In Abstracts of the Fourth European Conodont Symposium (ECOS IV) (Aldridge, R. J., Austin, R. L. \& .Smith, M. P., eds.). Nottingham, 8-9.

Dineley, D. L. \& Loeffler, E. J. 1976. Ostracoderm Faunas of the Delorme and Associated SiluroDevonian Formations, North West Territories, Canada. Spec. Pap. Palaeontol., 18.

Dixon, J., Williams, R. \& Turner, S. 1972. Stratigraphical setting of the Silurian thelodonts from Prince of Wales Island, Northwest Territories. Lethaia, 5, 281-282.

Elliott, D. K. 1984. Siluro-Devonian fish biostratigraphy of the Canadian Arctic islands. Proc. Linn. Soc. N.S.W., 107, 3, 197-209.

Elliott, D. K. \& Loeffler, E. J. 1989. A new agnathan from the Lower Devonian of Arctic Canada, and a review of the tessellated heterostracans. Palaeontology, 32, 4, 883-891.

Jeppsson, L. 1972. Some Silurian conodont apparatuses and possible conodont dimorphism. Geol. Palaeontol., 6, 51-69.

Jeppsson, L. 1996. Silurian events - a review of the knowledge in 1996. In The James Hall Symposium: Second International Symposium on the Silurian System. August 4-9, 1996. Program and Abstracts. University of Rochester, N.Y., 59.

Jeppsson, L. A new lower and middle Wenlock standard conodont zonation. Trans. Roy. Soc. Edinb. (in press). 
Jeppsson, L., Aldridge, R. J. \& Dorning, K. J. 1995. Wenlock (Silurian) oceanic episodes and events. J. Geol. Soc. London, 152, 487-498.

Jeppsson, L. \& Männik, P. 1993. High-resolution correlations between Gotland and Estonia near the base of the Wenlock. Terra Nova, 5, 348-358.

Jeppsson, L., Viira, V. \& Männik, P. 1994. Silurian conodont-based correlations between Gotland (Sweden) and Saaremaa (Estonia). Geol. Mag., 131, 2, 201-218.

Kaljo, D., Kiipli, T. \& Martma, T. 1996. Carbon isotope event stratigraphy of the East Baltic Silurian. In The Third Baltic Stratigraphical Conference. Abstracts. Field Guide (Meidla, T., Puura, I., Nemliher, J., Raukas, A. \& Saarse, L., eds.). Tartu, 31-32.

Kaljo, D., Kiipli, T. \& Martma, T. 1997. Carbon isotope event markers through the WenlockPridoli sequence in Ohesaare (Estonia) and Priekule (Latvia). Palaeo. Palaeo. Palaeo., 132, 1-4, 211-224.

Kaljo, D., Kiipli, T. \& Martma, T. Carbon isotope event stratigraphy of the East Baltic Silurian. Rochester Symposium Volume (in press).

Karatajūte-Talimaa, V. 1978. Telodonty silura i devona SSSR $i$ Spitsbergena. Vilnius (in Russian).

Karatajūte-Talimaa, V. \& Predtechenskyj, N. 1995. The distribution of the vertebrates in the Late Ordovician and Early Silurian palaeobasins of the Siberian Platform. Bull. Mus. Nat. Hist. Nat., Paris, 4, 39-55.

Märss, T. 1992. Vertebrate history in the Late Silurian. Proc. Estonian Acad. Sci. Geol., 41, 4, 205-214.

Märss, T. 1997. Vertebrates of the Pridoli and Silurian-Devonian boundary beds in Europe. Mod. Geol., 21, 1/2, 17-42.

Märss, T., Männik, P., Martma, T., Wilson, M. V. H., Caldwell, M. W., Thorsteinsson, R., Gagnier, P.-Y. \& Goujet, D. 1997. Distribution of Silurian vertebrate microremains in Baillie-Hamilton and Cornwallis Island sections, Arctic Canada. In Circum-Arctic Palaeozoic Vertebrates: Biological and Geological Significance. Ichthyolith Issues Spec. Publ. 2, 20-22.

Märss, T. \& Ritchie, A. 1998. Articulated thelodonts (Agnatha) of Scotland. Trans. Roy. Soc. Edinb.: Earth Sci., 88, 3, 143-195.

Mayr, U., Uyeno, T. T., Tipnis, R. S. \& Barnes, C. R. 1980. Subsurface stratigraphy and conodont zonation of the Lower Paleozoic succession, Arctic Platform, southern Arctic Archipelago. Geol. Surv. Can. Pap. 80-1A, 209-215.

Murphy, M. A. \& Berry, W. B. N. 1983. Early Devonian conodont-graptolite collation and correlations with brachiopods and coral zones, central Nevada. Bull. Am. Assoc. Pet. Geol., 67, 371-379.

Ning Zhang, 1989. Wenlockian (Silurian) brachiopods of the Cape Phillips Formation, BaillieHamilton Island, Arctic Canada: Part I. Palaeontographica. Abt. A, 206, 49-97.

Obruchev, D. V. 1964. Vet'v Agnatha. Beschelyustnye. In Osnovy paleontologii. Beschelyustnye $i$ ryby (Obruchev, D. V., ed.). Nauka, Moscow, 34-116.

Ritchie, A. 1985. Ainiktozoon loganense Scourfield, a protochordate from the Silurian of Scotland. Alcheringa, 9, 117-142.

Rohr, D. M., Boucot, A. J. \& Perry, D. G. 1981. Silurian (Wenlockian) gastropods from BaillieHamilton Island, Canadian Arctic. J. Paleont., 55, 2, 331-339.

Sprague, D. J. 1977. Siluro-Devonian Thelodonts from the Cape Phillips Formation, Devon Island, Northwest Territories. Department of Earth Sciences, University of Waterloo (unpublished thesis of BS degree).

Thorsteinsson, R. 1958. Cornwallis and Little Cornwallis Islands, District of Franklin, Northwest Territories. Geol. Surv. Can. Mem., 294.

Thorsteinsson, R. 1967. Preliminary note on Silurian and Devonian ostracoderms from Cornwallis and Somerset Islands, Canadian Arctic Archipelago. In Problèmes Actuels de Paléontologie (Evolution des Vertébrés). Colloques Internationaux du Centre National de la Recherche Scientifique, Paris, 163, 45-47. 
Thorsteinsson, R. \& Uyeno, T. T. 1980. Stratigraphy and Conodonts of Upper Silurian and Lower Devonian Rocks in the Environs of the Boothia Uplift, Canadian Arctic Archipelago. Geol. Surv. Can. Bull., 292.

Traquair, R. H. 1898. Report on fossil fishes collected by the Geological Survey of Scotland in the Silurian rocks of the South of Scotland. Trans. Roy. Soc. Edinb., 39, 827-864.

Turner, S. 1982. A new articulated thelodont (Agnatha) from the Early Devonian of Britain. Palaeontology, 25, 4, 879-889.

Turner, S. \& Dixon, J. 1970. Lower Silurian thelodonts from Prince of Wales Island, Northwest Territories. Lethaia, 4, 385-392.

Uyeno, T. T. 1977. Summary of conodont biostratigraphy of the Read Bay Formation at its type sections and adjacent areas, eastern Cornwallis Island, District of Franklin. Geol. Surv. Can. Pap. 77-1B, 211-216.

Uyeno, T. T. 1989. A biostratigraphic summary based primarily on conodonts of Upper Ordovician to Middle Devonian rocks of southwestern Ellesmere Island and northwestern Devon Island, Canadian Arctic Archipelago. Geol. Surv. Can. Pap. 89-1G, 241-247.

Uyeno, T. T. 1990. Biostratigraphy and Conodont Faunas of Upper Ordovician Through Middle Devonian Rocks, Eastern Arctic Archipelago. Geol. Surv. Can. Bull., 401, 1-210.

Vieth, J. 1980. Thelodontier-, Acanthodier- und Elasmobranchier-Schuppen aus dem Unter-Devon der Kanadischen Arktis (Agnatha, Pisces). Göttinger Arb. Geol. Paläont., 23, 69.

Viira, V. 1982. Shallow-water conodont Ctenognathodus murchisoni (Late Wenlock, Estonia). In Communities and Biozones in the Baltic Silurian (Kaljo, D. \& Klaamann, E., eds.). Valgus, Tallinn, 63-83.

\section{SILURI SELGROOGSETE MIKROJÄÄNUSTE JA KONODONTIDE LEVIK BAILLIE-HAMILTONI JA CORNWALLISE SAARE LÄBILÕIGETES KANADA ARKTIKAS}

\section{Tiiu MÄRSS, Michael CALDWELL, Pierre-Yves GAGNIER, Daniel GOUJET, Peep MÄNNIK, Tõnu MARTMA ja Mark WILSON}

1994. aasta ekspeditsioonil Baillie-Hamiltoni ja Cornwallise saartele Kanada Arktikas võeti varajaste selgroogsete skeletielementide uurimiseks 130 proovi siluri ja alamdevoni läbilõigetest. Nende kahe saare vastavates läbilõigetes on telodondid esindatud peamiselt perekondadega Loganellia, Shielia, Goniporus, Katoporodus, Nikolivia, Canonia ja Turinia ning seitsme uue perekonnaga. Anaspiidide neli (kolm?) ja kõhrkalade kolm perekonda on kindlaks tehtud esmakordselt. Akantoodidest on määratud perekondade Nostolepis, Gomphonchus ja Poracanthodes liigid. On välja eraldatud kümme selgroogsete kompleksi, mis võivad olla aluseks läbilõigete biostratigraafilisel liigestamisel.

Baillie-Hamiltoni 1. läbilõike alumine pool ja Phillipsi neeme läbilõike keskosa on Hilis-Llandovery vanusega (Pterospathodus amorphognathoides'e tsoon). Baillie-Hamiltoni 2. läbilõike keskosa aga vastab ilmselt juba Hilis-Wenlockile. Washington Pointi läbilõike keskosas ilmuv konodondifauna on devoni vanusega. Readi lahest (Read Bay) lõunasse jääv läbilõige vastab valdavas osas Přidolile, kuid selle alumises osas esinevad ?Ligonodina confluens ja Pedavis? 
sp. lubavad seda intervalli korreleerida ka Ludlow kõige ülemiste kihtidega. Ozarkodina cf. eurekaensis'e ilmumine läbilõike ülemises osas viitab Lochkovi vanusele.

Süsiniku isotoopide väärtuste kõvera iseloom Kanada Arktika läbilõigetes on võrreldav Baltikumi omaga Wenlocki, Ludlow ja Přidoli osas ning Kesk-Uraali kõveraga siluri-devoni piirikihtides.

\title{
РАСПРОСТРАНЕНИЕ МИКРООСТАТКОВ СИЛУРИЙСКИХ ПОЗВОНОЧНЫХ И КОНОДОНТОВ В РАЗРЕЗАХ ОСТРОВОВ БЕЙЛЛИ-ГАМИЛЬТОН И КОРНУОЛЛИС КАНАДСКОЙ АРКТИКИ
}

\author{
Тийу МЯРСС, Майкл КОЛДВЭЛЛ, Пьер-Ив ГАНЬЕ, Даниель ГУЖЕ, \\ Пеэп МЯННИК, Тыну МАРТМА и Марк ВИЛЬСОН
}

В ходе экспедиции 1994 г. на о-ва арктической зоны Канады БейллиГамильтон и Корнуоллис были отобраны 130 проб из силурийских и нижнедевонских разрезов в целях выявления в них микроостатков ранних вертебрат.

В силурийских разрезах названных островов телодонты представлены в основном родами Loganellia, Shielia, Goniporus, Katoporodus, Nikolivia, Canonia и Turinia, а также семью новыми родами. Четыре (три?) рода анаспид и три рода хрящевых рыб, кроме Ellesmereia, обнаружены впервые. Из акантодов определены виды родов Nostolepis, Gomphonchus и Poracanthodes. Выделены десять комплексов позвоночных, которые могут быть использованы в качестве основы для биостратиграфического расчленения разрезов.

Нижняя половина разреза Бейлли-Гамильтон 1 и средняя часть разреза мыса Филлипса относятся к позднему лландовери (зона Pterospathodus amorphognathoides). Средняя часть разреза Бейлли-Гамильтон 2 соответствует, вероятно, верхам венлока. Средняя часть разреза Вашингтон Пойнт, судя по обновленному составу конодонтовой фауны, принадлежит девону. Разрез южнее залива Рид Бей соотносится в основном с пржидолью, хотя самые нижние слои с ?Ligonodina confluens и Pedavis? sp. позволяют коррелировать этот интервал с самыми верхними слоями лудлова. Появление Ozarkodina cf. eurekaensis в верхах разреза свидетельствует об их лохковском возрасте.

Анализ изотопного углерода показывает схожесть кривых изменения $\delta^{13} \mathrm{C}$ в разрезах арктической зоны Канады, Прибалтики, о-ва Готланд и Среднего Урала. В этих регионах максимумы изотопно-углеродных кривых в венлоке, лудлове, пржидоли и нижнем девоне коррелируются между собой. 